\title{
KEPERCAYAAN DAN PERSEPSI RISIKO TERHADAP KEAMANAN KONSUMEN DAN IMPLIKASINYA TERHADAP MINAT BELI KONSUMEN DI MARKETPLACE SHOPEE KOTA JAMBI
}

\author{
Ananda Dewi Wahyuni ${ }^{1)}$,Dahmiri ${ }^{2}$ \\ ${ }^{1,2)}$ Magister Manajemen FEB Universitas Jambi \\ Ananda.dewi.wahyuni@gmail.com
}

\begin{abstract}
Abstrak
Banyaknya perusahaan e-commerce yang ada di Indonesia menyebabkan kompetisi yang ketat untuk menarik minat seseorang dalam berkunjung dan melakukan pembelian melalui situs miliknya. Beberapa faktor yang memiliki pengaruh terhadap minat beli seseora ng adalah kepercayaan, persepsi risiko dan keamanan. Oleh karena itu, penelitian ini bertujuan untuk mengetahui hubungan kepercayaan dan persepsi resiko terhadap keamanan konsumen dan implikasinya terhadap minat beli konsumen di marketplace Shopee kota Jambi. Teknik pengambilan sampel dalam penelitian ini menggunakan nonprobability sampling atau tepatnya purposive sampling dengan 100 responden yang merupakan warga Kota Jambi yang menggunakan e-commerce Shopee. Analisis data dilakukan dengan menggunakan metode Structural Equation Modeling (SEM) berbasis PLS yang diolah dengan software Smart PLS 3.2.8. Hasil penelitian ini menunjukan bahwa kepercayaan konsumen dan Persepsi risiko memiliki pengaruh positif signifikan terhadap keamanan konsumen. Sedangkan keamanan konsumen berpengaruh positif signifikan terhadap minat beli konsumen.
\end{abstract}

Kata Kunci: e-commerce, Minat Beli Konsumen, Persepsi Risiko, kepercayaan konsumen dan keamanan konsumen.

\begin{abstract}
The number of e-commerce companies in Indonesia causes intense competition to attract someone to visit and purchases through their site. Some of the factors that have an influence on a person's purchase intention are trust, risk perception and security. Therefore, this study aims to determine the relationship between trust and risk perception on consumer safety and its implications for consumer buying interest in the Shopee marketplace, Jambi city. The sampling technique in this study used non-probability sampling or rather purposive sampling with 100 respondents who were residents of Jambi City who used Shopee e-commerce. Data analysis was performed using the PLS-based Structural Equation Modeling (SEM) method processed with SmartPLS 3.2.8 software. The results of this study indicate that consumer trust and risk perception have a significant positive effect on consumer safety. Meanwhile, consumer safety has a significant positive effect on consumer buying interest.
\end{abstract}

Keywords: e-commerce, consumer buying interest, risk perception, trust consumers and consumer safety

\section{PENDAHULUAN}

Di Indonesia, belanja secara online telah menjadi pilihan banyak pihak untuk memperoleh barang. Pertumbuhan e-commerce yang terus meningkat di Indonesia membuat Shopee ikut meramaikan industri ini. Menurut hasil riset yang lakukan oleh 
iPrice yang merupakan situs pembanding harga produk yang dijual di berbagai $e$ commerce terpercaya di Indonesia, Shopee menempati posisi pertama sebagai e-commerce paling populer di Indonesia bahkan di Asia Tenggara pada periode Triwulan III tahun 2019, dijelaskan dengan gambar berikut:

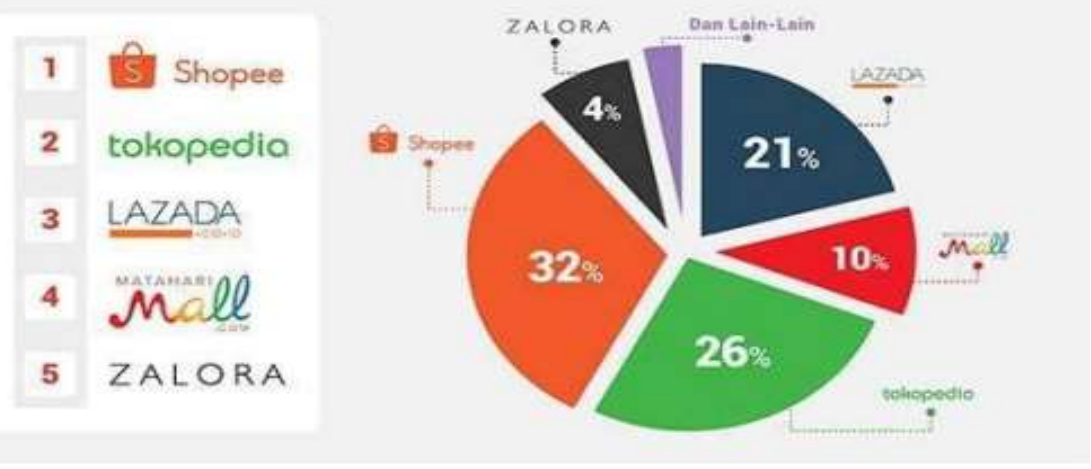

Gambar 1. E-Commerce Dengan Pengunjung Terbesar Kuartal III-2019

Berdasarkan gambar di atas, Shopee menjadi pilihan utama masyarakat untuk berbelanja online yaitu sekitar 32\%. Setelah itu Tokopedia (26\%), Lazada (21\%), Matahari Mall (10\%), dan Zalora (4\%). Shopee menduduki peringkat pertama yang menjadi pilihan utama masyarakat dalam berbelanja karena Shopee dinilai memberikan banyak keunggulan dibandingkan online shop yang lainnya di mana salah kelebihannya yaitu terdapat banyak promo-promo menarik seperti harga yang relatif murah dan banyaknya kupon diskon, potongan ongkir bahkan free ongkir seluruh Indonesia dan yang terbaru fitur bayar ditempat (Cash On Delivery) sehingga menarik banyak minat beli konsumen dibandingkan online shop lainnya.

Seiring dengan kemajuan pesat teknologi, dunia bagaikan tanpa batas (borderless), Shopee berdiri di Indonesia pada tahun 2015 tepatnya pada hari Selasa (1/12/2015). Shopee sendiri telah diluncurkan secara terbatas pada awal 2015, yang merupakan aplikasi mobile e-commerce berbasis marketplace pertama bagi konsumen-ke-konsumen (C2C) yang aman, menyenangkan, mudah, dan praktis dalam jual beli. Platform ini menawarkan berbagai macam produk, dilengkapi dengan metode pembayaran yang aman, layanan pengiriman yang terintegrasi dan fitur sosial yang inovatif untuk menjadikan jual beli menjadi lebih menyenangkan, aman, dan praktis.

Shopee sebagai salah satu situs wadah jual beli secara online, telah melakukan perubahan untuk menarik minat pelanggan agar lebih banyak bertransaksi melalui situs tersebut. Shopee lebih fokus pada platform 3 mobile sehingga orang-orang lebih mudah mencari, berbelanja, dan berjualan langsung di ponselnya saja. Shopee juga dilengkapi dengan fitur live chat, berbagi (social sharing), dan hashtag untuk memudahkan komunikasi antara penjual dan pembeli serta memudahkan dalam mencari produk yang diinginkan konsumen. Aplikasi Shopee dapat diunduh dengan gratis di App Store dan Google Play Store. Jika e-commerce Shopee mampu memberikan pelayanan yang tepat dan sesuai dengan harapan konsumen, maka Shopee akan memiliki persepsi baik di mata konsumen. Adapun cara yang di lakukan oleh e-commerce Shopee dalam memberikan layanan berupa keamanan konsumen, kepercayaan dan persepsi resiko yaitu dengan cara menggunakan hal-hal yang sedang viral atau tren untuk pemasaran karena akan memudahkan masyarakat untuk mengingat platform tersebut.

Banyaknya promosi untuk pelanggan seperti gratis ongkos kirim merupakan salah satu alasan yang disukai konsumen dalam aplikasi ini. Hingga saat ini, platform ini masih 
memberikan promo gratis ongkos kirim untuk para penggunanya. Ongkos kirim diberikan dengan batas pembelian tertentu. Meski nominalnya tidak terlihat besar, bagi calon konsumen, gratis ongkir bisa jadi daya tarik yang memikat. Kemudian Menjaga keamanan akun adalah prioritas utama e-commerce Shopee. Sementara Shopee melakukan hal terbaik untuk memastikan setiap akun yang dimiliki konsumen selalu aman, dan menjaga dan melindungi informasi pribadi konsumen.

Berdasarkan latar belakang di atas, maka penulis tertarik untuk membuat suatu karya ilmiah berupa Tesis dengan judul "Kepercayaan Dan Persepsi Risiko Terhadap Keamanan Konsumen Dan Implikasinya Terhadap Minat Beli Konsumen Di Marketplace Shopee Kota Jambi"

\section{Rumusan Masalah}

Berdasarkan uraian yang sudah dijelaskan dalam latar belakang di atas, maka permasalahan dalam penelitian ini dapat dirumuskan sebagai berikut :

1. Bagaimana pengaruh Kepercayaan, dan Persepsi Risiko, terhadap persepsi keamanan konsumen di Marketplace Shopee Kota Jambi?

2. Bagaimana pengaruh persepsi Keamanan konsumen terhadap Minat beli Konsumen di Marketplace Shopee Kota Jambi ?

3. Bagaimana pengaruh Kepercayaan, dan Persepsi Risiko, melalui persepsi Keamanan Konsumen terhadap Minat beli konsumen di Marketplace Shopee Kota Jambi ?

\section{Tujuan Penelitian}

Berdasarkan latar belakang dan rumusan masalah di atas, maka tujuan yang akan dicapai dalam penelitian ini adalah untuk mengetahui :

1. Untuk Mengetahui Pengaruh Kepercayaan, Dan Persepsi Risiko, Terhadap Keamanan Konsumen di Marketplace Shopee Kota Jambi

2. Untuk Mengetahui Pengaruh persepsi Keamanan Konsumen, Terhadap Minat Beli Konsumen di Marketplace Shopee Kota Jambi.

3. Untuk Menjelaskan Pengaruh Kepercayaan, Dan Persepsi Risiko, Melalui Keamanan Konsumen Terhadap Minat Beli Konsumen, di Marketplace Shopee Kota Jambi.

\section{KAJIAN PUSTAKA}

\section{Minat Beli}

Minat beli menurut Pramono (2012), Willingness To Buy, merupakan bagian dari komponen perilaku dalam sikap mengkonsumsi. Minat beli konsumen adalah tahap dimana konsumen membentuk pilihan mereka diantara beberapa merek yang tergabung dalam perangkat pilihan, kemudian pada akhirnya melakukan suatu pembelian pada suatu altenatif yang paling disukainya atau proses yang dilalui konsumen untuk membeli suatu barang atau jasa yang didasari oleh bermacam pertimbangan. Minat beli juga merupakan instruksi diri konsumen untuk melakukan pembelian atas suatu produk, melakukan perencanaan, mengambil tindakan-tindakan yang relevan seperti mengusulkan, merekomendasikan, memilih dan akhirnya mengambil keputusan untuk melakukan pembelian

\section{Kepercayaan}

Kepercayaan konsumen menurut Ariwibowo (2013) adalah semua pengetahuan yang dimiliki oleh konsumen dan semua kesimpulan yang dibuat oleh konsumen tentang objek, atribut dan manfaatnya. Maksud dari objek disini adalah berupa produk, orang, perusahaan 
dan segala sesuatu dimana seseorang memiliki kepercayaan dan sikap. Kepercayaan dapat diwujudkan apabila sebuah produk telah memenuhi harapan dan kebutuhan konsumen, dimana mereka akan puas terhadap produk tersebut.

\section{Persepsi Risiko}

Persepsi Risiko didefinisikan oleh Dwi P. J, (2013) sebagai persepsi konsumen mengenai ketidakpastian dan konsekuensi-konsekuensi negatif yang mungkin diterima atas pembelian suatu produk atau jasa. Persepsi risiko menjadi salah satu komponen penting dalam pemprosesan informasi yang dilakukan oleh konsumen. Konsumen semakin terdorong untuk mencari tambahan informasi ketika dihadapkan pada pembelian produk dengan risiko tinggi.

\section{Keamanan}

Wu \& Chen, (2014) mendefinisikan keamanan sebagai kemampuan toko online dalam melakukan pengontrolan dan penjagaan keamanan atas transaksi data. Lebih lanjut $\mathrm{Wu} \&$ Chen, (2014) mengatakan bahwa jaminan keamanan berperan penting dalam pembentukan kepercayaan dengan mengurangi perhatian konsumen tentang penyalahgunaan data pribadi dan transaksi data yang mudah rusak. Ketika level jaminan keamanan dapat diterima dan bertemu dengan harapan konsumen, maka seorang konsumen mungkin akan bersedia membuka informasi pribadinya dan akan membeli dengan perasaan aman.

\section{E-Marketplace}

E-Marketplace merupakan media online berbasis internet (web based), tempat melakukan kegiatan bisnis dan transaksi antara pembeli dan penjual. Pembeli dapat mencari supplier sebanyak mungkin dengan kriteria yang diinginkan, sehingga memperoleh barang sesuai harga pasar. Sedangkan bagi supplier/penjual dapat mengetahui perusahaan-perusahaan yang membutuhkan produk/jasa mereka (Opiida, 2014). EMarketplace merupakan model E-Business yang berhubungan dengan penjual dan pembeli (seller \& buyer). E-Marketplace di Indonesia merupakan salah satu media penggerak ekonomi nasional dalam rangka menghadapi era globalisasi. Untuk itu, perlu dikembangkan marketplace yang teratur, wajar dan efisien. E-marketplace adalah wadah komunitas bisnis interaktif secara elektronik yang menyediakan pasar dimana perusahaan dapat ambil andil dalam B2B e-commerce dan atau kegiatan bisnis lain.

\section{Kerangka Pemikiran}

Penelitian ini meneliti tentang Kepercayaan dan Persepsi Resiko terhadap keamanan konsumen dan implikasinya terhadap minat beli konsumen di Marketplace Shopee Kota Jambi. Untuk lebih jelasnya, dapat dilihat pada gambar berikut :

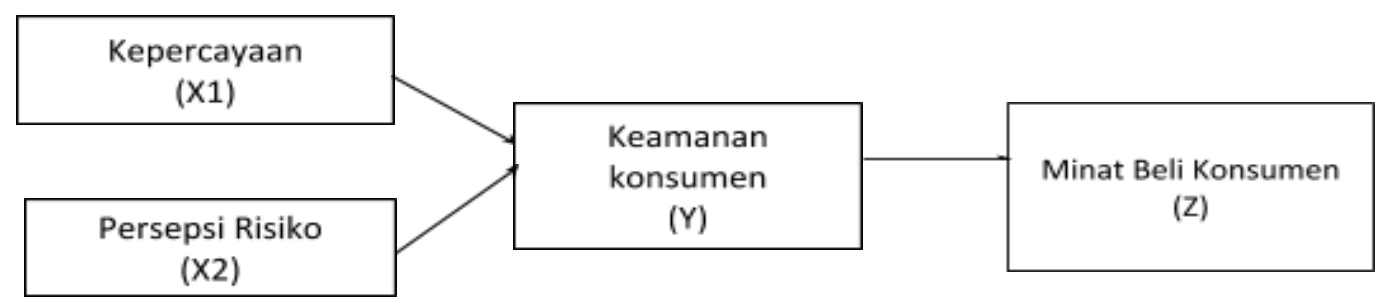

Gambar 1.Kerangka Pemikiran 


\section{Hipotesis}

Berdasarkan gambar 2.2 di atas, maka hipotesis penelitian menjadi sebagai berikut :

$\mathrm{H}_{1}$ : Kepercayaan konsumen berpengaruh signifikan terhadap keamanan konsumen

$\mathrm{H}_{2}$ : Persepsi risiko berpengaruh signifikan terhadap keamanan konsumen

$\mathrm{H}_{3}$ : Keamanan konsumen memberikan pengaruh yang signifikan terhadap minat beli konsumen

$\mathrm{H}_{4}$ : Kepercayaan melalui keamanan konsumen memberikan pengaruh yang signifikan terhadap minat beli konsumen.

$\mathrm{H}_{5}$ : Persepsi risiko melalui keamanan konsumen memberikan pengaruh yang signifikan terhadap minat beli konsumen.

\section{METODE PENELITIAN}

\section{Desain Penelitian}

Mengacu pada rumusan masalah dan bentuk data pada penelitian ini, maka metode estimasi yang digunakan untuk menguji hipotesis pada penelitian ini adalah metode kuantitatif, dimana pendekatan kuantitatif merupakan metode yang berupaya menguantifikasi data dengan menerapkan teknik analisis statistik tertentu. Berdasarkan jenisnya penelitian ini bersifat deskriptif dengan metode observasional, dimana penelitian ini dimaksudkan untuk eksplorasi, verifikasi dan klarifikasi terhadap sebuah fenomena sosial, dengan mendeskripsikan sejumlah variabel yang relevan dengan fenomena tersebut. Adapun fenomena yang dimaksudkan pada penelitian ini adalah fenomena belanja online.

\section{Populasi dan Sampel}

Populasi adalah wilayah generalisasi yang terdiri atas: obyek/subyek yang mempunyai kualitas dan karakteristik tertentu yang ditetapkan oleh peneliti untuk dipelajari dan kemudian di tarik kesimpulanya. Dalam penelitian ini jumlah populasinya adalah seluruh warga kota Jambi yang menggunakan $e$-commerce Shopee yang jumlahnya tidak diketahui secara pasti.

Sampel dalam penelitian ini adalah anak muda kota jambi yang aktif menggunakan marketplace Shopee selama dua tahun terakhir dan pernah melakukan pembelian produk di marketplace Shopee. Dengan demikian besaran sampel pada penelitian ini bersifat relatif tergantung pada hasil observasi di lapangan. Akan tetapi jumlah minimum sampel pada penelitian ini dapat ditentukan dengan menggunakkan Rumus Slovin, dengan perhitungan sebagai berikut:

$$
n=\frac{N}{1+(N \cdot \operatorname{sig})}
$$

Dimana:

$\mathrm{n} \quad=$ ukuran sampel minimum

$\mathrm{N}=$ jumlah populasi

Sig $=$ taraf kepercayaan $10 \%$ atau 0,01

Dengan demikian sampel minumun dapat diperoleh sebagai berikut:

$$
\begin{aligned}
\text { Sampel minimum } & =\frac{284.018}{1+(284.018 \times 0,01)} \\
& =99,965 \text { atau dibulatkan menjadi } \\
& =100 \text { responden }
\end{aligned}
$$


Berdasarkan uraian di atas, diketahui bahwa sampel minimum pada penelitian ini adalah 100 responden.

\section{Teknik Analisis Data}

Model Analisis Structural Equation Modeling (SEM)

Menurut Ghozali (2012), SEM merupakan alat analisis yang dapat digunakan untuk mengonfirmasi apakah data observasi maupun variabel yang digunakan dalam model sudah sesuai secara teoritis. Selanjutnya, pengembangan model teoritis menjadi mutlak untuk memenuhi syarat kausalitas dalam penelitian.

\section{Structural Equation Modeling - Partial Least Square (SEM PLS)}

Berdasarkan bentuk datanya penelitian ini merupakan penelitian SEM berbasis PLS. Pada SEM berbasis PLS nilai variabel laten diestimasi sesuai kombinasi linear dari variabel-variabel manifest yang terkait dengan variabel laten serta diperlakukan untuk mengganti variabel manifest. Pada penelitian ini jenis data yang digunakan berbentuk ordinal atau tidak memiliki origin, sehingga secara teoritis lebih cocok menggunakan SEM berbasis PLS ketimbang berbasis kovarian.

\section{Uji Goodness Of Fit Outer Model Validitas}

Karena validitas diskriminan berhubungan dengan prinsip bahwa pengukur konstruk yang berbeda seharusnya tidak berkorelasi tinggi, maka validitas diskriminan dari model pengukuran refleksif dapat dihitung berdasarkan nilai cross loading dari variabel manifest terhadap masing-masing variabel laten. Apabila kolerasi antara variabel laten dengan setiap indikatornya (variabel manifest) lebih besar daripada korelasi dengan variabel laten lainnya, maka variabel laten tersebut dapat dikatakan memprediksi indikatornya lebih baik daripada variabel laten lainnya.Validitas diskriminan dapat dikatakan tercapai apabila nilai AVE lebih besar dari 0,5 (Sarwono dan Narimawati, 2015). AVE dapat ditentukan dengan menggunakan perumusan sebagai berikut:

$$
\operatorname{AVE}=\frac{\sum \lambda_{\mathrm{i}}^{2}}{\sum \lambda_{\mathrm{i}}^{2}+\sum_{\mathrm{i}} \operatorname{var}\left(\varepsilon_{\mathrm{i}}\right)}
$$

\section{Reliabilitas}

Pendekatan yang dapat dilakukan untuk menilai reliabilitas model pengukuran yaitu uji construct reliability pada masing-masing variabel laten. Perhitungan construct reliability sangat berguna untuk membangun validitas konvergen yang menggambarkan bahwa setiap variabel yang digunakan benar-benar signifikan dalam hal mencerminkan variabel konstruk atau laten. Nilai batas (cut off) dari construct reliability diterima apabila nilainya > 0,7 (Hair et al., 2010). Variance Extracted dengan besar setidaknya > 0,5 memiliki ketentuan nilai yang semakin tinggi sehingga menunjukkan indikator-indikator sudah mewakili konstruk laten.

Ukuran construct reliability dan Variance Extracted dapat dihitung dengan rumus sebagai berikut (Hair et al., 2010):

$$
\begin{aligned}
\text { Construct Reliability } & =\frac{\left(\sum \text { Std.loading }\right)^{2}}{\left(\sum \text { Std.loading }\right)^{2}+\sum \varepsilon} \\
\text { Variance Extracted } & =\frac{\left(\sum \text { Std.loading }\right)^{2}}{\left(\sum \text { Std.loading }\right)^{2}+\sum \varepsilon}
\end{aligned}
$$




\section{Pengukuran Inner Model}

Pengukuran bagian dalam merupakan bagian dari model SEM yang menggambarkan hubungan antar variabel-variabel laten atau antar variabel eksogen dengan variabel endogen. Pengujian inner model atau struktural model dapat dilakukan dengan melihat nilai R-squared. Menurut Ghozali (2012), hasil R2 sebesar 0,67 mengindikasikan bahwa model dikategorikan baik. Hasil R2 diantara 0,33 dan 0,67 mengindikasikan bahwa model dikategorikan moderat. Sedangkan Hasil R2 sebesar 0,33 mengindikasikan bahwa model dikategorikan lemah.

\section{Uji Signifikansi}

Uji signifikansi bertujuan untuk mengetahui besar pengaruh variabel independen terhadap variabel dependen. Uji signifikansi pada model SEM dengan PLS, yang dimaksud dengan variabel independen adalah variabel laten eksogen dan yang dimaksud dengan variabel dependen adalah variabel laten endogen. Nilai estimasi untuk hubungan jalur dalam model struktural digunakan untuk mengetahui signifikansi dari hubunganhubungan antar variabel laten. Nilai signifikan dapat diperoleh dengan prosedur bootstrapping yang dikembangkan oleh Geisser \& Stone.

\section{HASIL DAN PEMBAHASAN}

\section{Analisis Data}

Structural Equation Modeling - Partial Least Square (SEM PLS)

Penelitian ini menggunakan analisis Structural Equation Modeling (SEM) berbasis varian (Partial Least Square). PLS-SEM ini bertujuan untuk menguji hubungan atau pengaruh antar konstruk variabel. Berikut hasil output calculate alghoritm dengan menggunakan software SMARTPLS 3.2.8

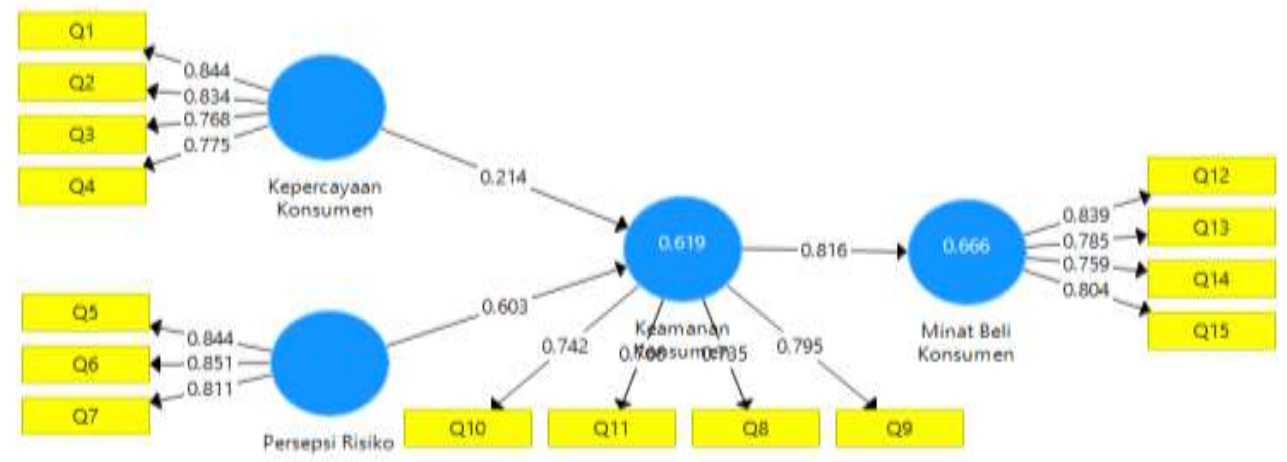

Sumber : Data Diolah

\section{Gambar Output Calculate Alghoritm}

Pada Gambar diatas menunjukkan hasil penelitian dari masing-masing variabel yaitu Kepercayaan Konsumen yang memiliki 4 indikator (Q1-Q4), Persepsi Risiko yang memiliki 3 indikator (Q5-Q7), keamanan Konsumen yang memiliki 4 indikator (Q8-Q11) dan variabel Minat Beli Konsumen yang memiliki 4 indikator (Q12-Q15). Arah panah antara indikator dengan variabel laten menunjukkan bahwa penelitian menggunakan indikator formatif yang bersifat mendefinisikan karakteristik atau menjelaskan variabel laten. 


\section{Uji Inner Model}

Uji Validitas

Pengujian validitas dalam penelitian ini dapat dilihat dari uji convergen validity. hasil output pengujian validitas dalam penelitian ini dapat dilihat di bawah ini :

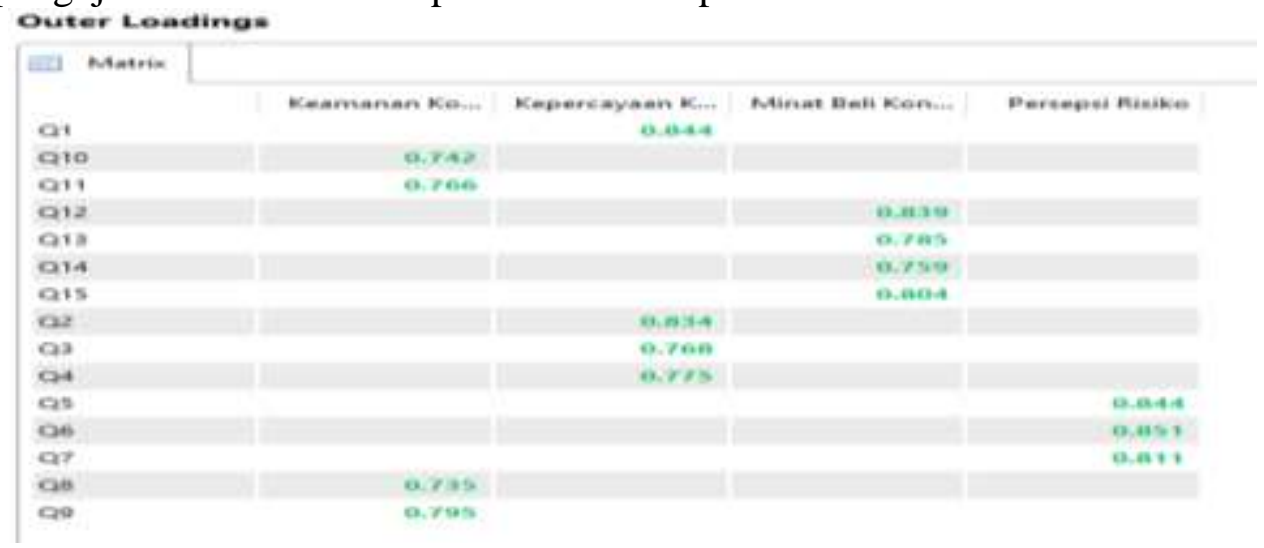

Gambar Hasil Outer Loadings

Gambar di atas menunjukkan bahwa nilai convergen validity dari setiap indikator terhadap variabel laten menunjukkan nilai lebih dari 0,5. Hal ini menunjukkan bahwa indikator pada setiap variabel yang digunakan oleh peneliti valid. Nilai indikator yang paling rendah adalah nilai indikator Q8 yaitu sebesar 0,735. Sedangkan nilai indikator yang paling tinggi adalah indikator Q6 sebesar 0,851. Dengan demikian semua indikator dalam penelitian ini di katakan valid dan memenuhi uji convergent validity.

\section{Uji Diskriminan}

Uji diskriminan dalam penelitian dilakukan dengan melihat nilai Average Variance Extracted (AVE). Hasil pengujian dapat dikatakan memenuhi uji diskriminan jika nilai AVE lebih dari 0,5. Berikut output nilai AVE :

\begin{tabular}{|c|c|c|c|c|c|c|c|}
\hline \multirow[t]{2}{*}{ Matrix } & \multicolumn{2}{|c|}{ 掉革 Cronbach's Alpha } & \multicolumn{2}{|c|}{ 势萃 rho_A } & \multicolumn{2}{|c|}{ Composite Reliability } & 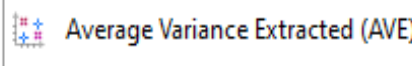 \\
\hline & & Cronbach & h's Al... & & rho_A & Composite Rel... & .. Average Varian... \\
\hline Keamanan & Konsumen & & 0.756 & & 0.759 & 0.845 & 0.577 \\
\hline Kepercaya & n Konsumen & & 0.820 & & 0.824 & 0.881 & 0.650 \\
\hline Minat Beli & Konsumen & & 0.809 & & 0.812 & 0.874 & 0.636 \\
\hline Persepsi Ri: & & & 0.785 & & 0.791 & 0.874 & 0.698 \\
\hline
\end{tabular}

\section{Gambar Hasil Average Variance Extracted (AVE)}

Dari gambar di atas, dapat diketahui bahwa nilai AVE variabel Keamanan Konsumen sebesar 0,577, Kepercayaan Konsumen sebesar 0,650, Minat Beli Konsumen sebesar 0,636 dan Persepsi Risiko sebesar 0,698. Dengan demikian, dari semua variabel nilai AVE menunjukkan angka di atas 0,5 . Hal ini berarti dari keseluruhan variabel yang digunakan dalam penlitian sudah memenuji uji diskriminan. 


\section{Uji Reabilitas}

Uji reabilitas pada penelitian diuji dengan melihat nilai crombach alpha dan composite reability, dimana variabel penelitian akan dinyatakan reliable jika hasil dari kedua nilai tersebut menunjukkan angka lebih dari 0,70. Berdasarkan hasil pengujian yang dilakukan oleh peneliti, berikut hasil output uji reliabilitas :

\begin{tabular}{|c|c|c|c|c|c|c|c|c|c|}
\hline \multirow[t]{2}{*}{ Matrix } & \multirow[t]{2}{*}{ 㩰筆 Cronba } & ch's Alpha & 㩰育 & rho_A & 㩰 & \multicolumn{2}{|c|}{ Composite Reliability } & \multicolumn{2}{|c|}{ 㩰策 Average Variance Extracted (AVE) } \\
\hline & & Cronbach & 's Al... & & & rho_A & Composite Rel... & . Average Varian... & \\
\hline \multicolumn{2}{|c|}{ Keamanan Konsumen } & & 0.756 & & & 0.759 & 0.845 & 0.577 & \\
\hline \multicolumn{2}{|c|}{ Kepercayaan Konsumen } & & 0.820 & & & 0.824 & 0.881 & 0.650 & \\
\hline \multicolumn{2}{|c|}{ Minat Beli Konsumen } & & 0.809 & & & 0.812 & 0.874 & 0.636 & \\
\hline \multicolumn{2}{|c|}{ Persepsi Risiko } & & 0.785 & & & 0.791 & 0.874 & 0.698 & \\
\hline
\end{tabular}

\section{Gambar Hasil Output Uji Reliabilitas}

Berdasarkan Gambar di atas, hasil uji reabilitas menggunakan cronbach's alpha dari variabel Keamanan Konsumen adalah sebesar 0,756, variabel Kepercayaan Konsumen sebesar 0,820, variabel Minat Beli Konsumen sebesar 0,809 dan variabel Persepsi Konsumen adalah sebesar 0,785. Berdasarkan hasil tersebut, dapat diketahui bahwa nilai cronbach's alpha dari semua variabel menunjukkan angka lebih dari 0,70. Sehingga berdasarkan semua variabel dalam penelitian ini dinyatakan reliable.

Sedangkan hasil uji reliabilitas menggunakan composite reliability dari variabel Keamanan Konsumen adalah sebesar 0,845, variabel Kepercayaan Konsumen sebesar 0,881, variabel Minat Beli Konsumen sebesar 0,874 dan variabel Persepsi Konsumen adalah sebesar 0,874. Berdasarkan hasil tersebut, dapat diketahui bahwa nilai composite reliability dari semua variabel menunjukkan angka lebih dari 0,70. Sehingga berdasarkan semua variabel dalam penelitian ini dinyatakan reliable.

\section{Uji Outer}

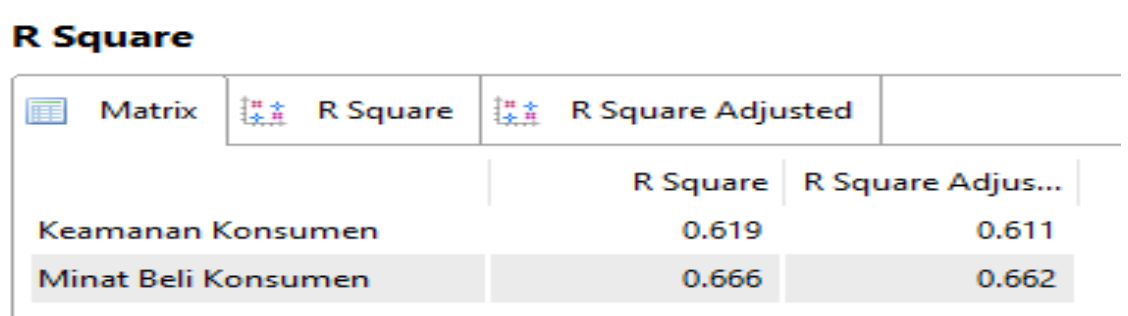

Gambar Hasil R-Square Adjusment $\left(\mathrm{R}^{2}\right)$

Berdasarkan Gambar di atas dapat dilihat bahwa nilai R-Square variabel Keamanan Konsumen sebesar 0,611. Hal ini menunjukkan bahwa variabel Keamanan Konsumen mampu menjelaskan pengaruhnya terhadap Minat Beli Konsumen sebesar 61,1\% dan sisanya 38,9\% dipengaruhi atau dijelaskan oleh variabel lain di luar model penelitian. Sedangkan nilai R-Square Minat Beli Konsumen sebesar 0,662. Hal ini berarti bahwa sebesar 62,2\% variabel Minat Beli Konsumen di jelaskan oleh variabel dalam penelitian dan sisanya $37,8 \%$ dijelaskan oleh variabel di luar model penelitian.

Uji $\boldsymbol{t}$

Uji t dalam penelitian ini dilakukan untuk mengetahui pengaruh variabel independen terhadap variabel dependen. Pengambilan keputusan pada pengujian ini dilakukan dengan 
melihat nilai t-statistics dan nilai p-value. H0 dapat diterima jika nilai t-statistik lebih besar dari t table $(1,67)$ dan nilai $\mathrm{p}$-value lebih kecil dari nilai taraf signifikansi (alpha) yaitu sebesar 5\%. Berikut hasil output uji t berdasarkan path coefficient.

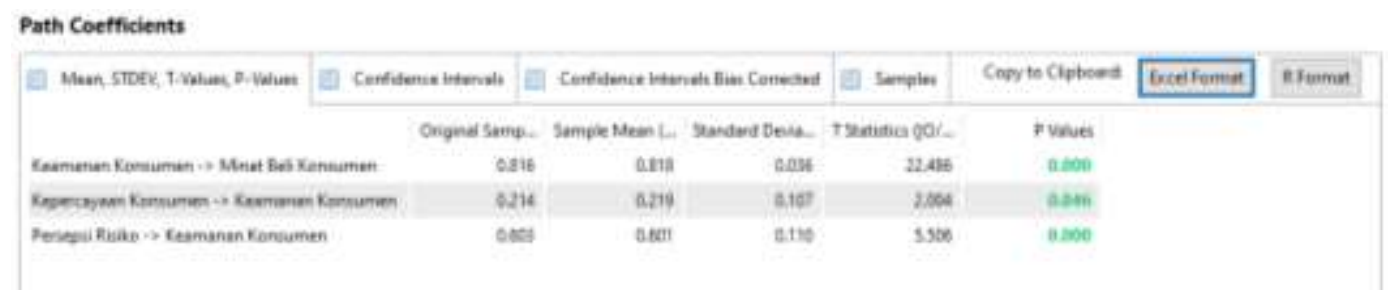

\section{Pembahasan}

Gambar Uji t

\section{Pengaruh Kepercayaan Terhadap Keamanan Konsumen di Marketplace Shopee Kota Jambi.}

Hasil penelitian yang dilakukan berdasarkan kuisioner yang diisi oleh para responden menunjukkan bahwa kepercayaan konsumen memiliki pengaruh signifikan terhadap keamanan konsumen. Hal ini dibuktikan dengan nilai t statistic dan p-value yang masingmasing sebesar 2.004 dan 0.046. Hal ini menunjukkan bahwa tinggi rendah-nya respons terhadap kepercayaan pada marketplace Shopee di Kota Jambi cenderung mempengaruhi respon terhadap tingkat keamanan pada marketplace tersebut.

\section{Pengaruh Persepsi Risiko Terhadap Keamanan Konsumen di Marketplace Shopee Kota Jambi.}

Hasil uji pengaruh persepsi risiko terhadap keamanan konsumen menunjukkan nilai tstatistik pada uji ini adalah sebesar 5.506 atau lebih besar dari t tabel $(1,67)$ dengan nilai pvalue sebesar 0.000 yang artinya menunjukkan pengaruh yang siginifikan. Hal ini menunjukkan bahwa terdapat pengaruh yang signifikan antara respons persepsi risiko masyarakat pada marketplace Shopee terhadap persepsi masyarakat terkait tingkat keamanan pada marketplace tersebut.

\section{Pengaruh Keamanan Konsumen Terhadap Minat Beli Konsumen di Marketplace Shopee Kota Jambi}

Hasil penelitian yang dilakukan berdasarkan kuisioner yang diisi oleh responden, diketahui bahwa variabel keamanan konsumen memiliki pengaruh yang signifikan terhadap minat beli konsumen dengan nilai t statistic sebesar 22.486 dan nilai p-value sebesar 0.000. Dengan demikian dapat disimpulkan bahwa persepsi masyarakat terhadap tingkat keamanan mempengaruhi respon mereka terhadap minat beli pada marketplace Shopee.

Pengaruh Kepercayaan dan Persepsi Risiko Melalui Keamanan Konsumen Terhadap Minat Beli Konsumen di Marketplace Shopee Kota Jambi

Hasil uji pengaruh kepercayaan dan persepsi risiko melalui keamanan konsumen terhadap minat beli konsumen di Marketplace Shopee Kota Jambi dapat dilihat berdasarkan nilai tstatistic pada hasil uji efek mediasi, yang mana hasil uji tersebut secara umum menunjukkan bahwa variabel keamanan konsumen dapat memediasi variabel kepercayaan dan persepsi resiko terhadap minat beli konsumen. 


\section{Simpulan Dan Saran \\ Simpulan}

Berdasarkan hasil pengolahan data, peneliti merumuskan beberapa kesimpulan penelitian seperti yang dijelaskan berikut ini :

a. Hasil penelitian menunjukkan bahwa kepercayaan konsumen dan persepsi resiko memiliki pengaruh signifikan terhadap persepsi keamanan konsumen.

b. Selanjutnya, Hasil uji pengaruh persepsi keamanan terhadap minat beli konsumen menunjukkan hasil yang signifikan. Hal ini menjelaskan bahwa minat beli konsumen secara signifikan dipengaruhi atas persepsi mereka pada tingkat keamanan pada marketplace tersbut.

c. Hasil uji pengaruh kepercayaan dan persepsi risiko konsumen terhadap minat beli konsumen melalui persepsi keamanan konsumen sebagai variabel moderating, menunjukkan pengaruh yang siginifkan, dengan demikian peningkatan minat beli dapat dilakukan melaui peningkatan aspek kaemanan konsumen.

\section{Saran}

Setelah melakukan penelitian, peneliti sadar bahwa beberapa aspek dalam penelitian masih belum sempurna. Oleh karena itu, peneliti merumuskan beberapa saran untuk penelitian selanjutnya yang akan melakukan penelitian serupa. Saran bagi penelitian selanjutnya diharapkan agar dapat menambahkan variabel-variabel lainnya yang lebih mendalam mengenai minat beli, mengingat variabel minat beli memiliki banyak faktorfaktor yang dapat lebih dikembangkan di penelitian selanjutnya.

Saran berikutnya adalah agar sampel yang digunakan juga lebih banyak, yang bertujuan untuk memperoleh konsistensi dan keakuratan dari hasil penelitian yang lebih besar.

\section{Daftar Pustaka}

AG.Suyono, Sri Sukmawati, Pramono. 2012. Pertimbangan Dalam Membeli Produk Barang Maupun Jasa. Intidayu Press. Jakarta.

Ariwibowo \& Nugroho. 2013. "Pengaruh Trust Dan Perceived Of Risk Terhadap Niat Untuk Bertransaksi Menggunakan E-Commerce.” Jurnal Nominal / Volume Ii Nomor I / Tahun 2013 As'alul

Arasu Raman, dan Viswanathan, A. 2011. Web Services and e-Shopping Decisions: A Study on Malaysian e-Consumer. IJCA Special Issue on:Wireless Information Networks \& Business Information System, hal.54-60.

Dan J. Kim et al., 2014 "A trust-based consumer decision-making model in electronic commerce: The role of trust, perceived risk, and their antecedents".

Durianto, Darmadi, Sugiarto, dan Toni, S. 2010, Strategi Menaklukkan Pasar Melalui Riset Ekuitas dan Perilaku Merek. Jakarta: Gramedia Pustaka Utama.

Dwi P. J, A .2013 dengan judul Pengaruh Trust Dan Perceived Of Risk Terhadap Niat Untuk Bertransaksi Menggunakan E-commerce.

Ferriyal Rositas. 2014. Pengaruh Kepercayaan (Trust) dan E-Security Seals Terhadap Minat Pembelian Konsumen Secara Online: Studi Pada Konsumen Kaspay.com Di Indonesia.

Ghozali, I. 2012. Aplikasi Analisis Multivariate Dengan Program IBM SPSS 20. Semarang: Badan Penerbit Universitas Diponegoro. 
Haryosasongko F, A. 2015. Pengaruh Persepsi Risiko, Persepsi Kemudahan, Dan Persepsi Manfaat Terhadap Minat Pembelian Online Pada Website Lazada.co.id di Kota Malang.

Jr et.al H. 2010. Multivariate Data Analysis (7th ed). United States : Pearson

Khan, N., Rahmani, S.H.R., Hoe, H.Y., \& Chen, T.B. 2015. Causal Relationships among Dimensions of Consumer-Based Brand Equity and Purchase Intention: Fashion Industry. Canadian Center of Science and Education, 10(1), 172-181

Mardalis, Ahmad dan Hastuti. 2017. "Pemanfaatan Media Sosial untuk membangun Kepercayaan Merk" : Prosiding ISBN: 978-602-361-067-9 Seminar Nasional Riset Manajemen \& Bisnis 2017 Fakultas Ekonomi dan Bisnis Universitas Muhammadiyah Surakarta

Monecke, A., dan Leisch,F. 2012. The Journal of Statistical Software. [Online]. Tersedia di: http://www.jstatsoft.org/.

Moch S, Imam S, Riyadi. 2012 Pengaruh Persepsi Risiko, Kemudahan Dan Manfaat Terhadap Keputusan Pembelian Secara Online (Survei Terhadap Pengguna Situs Website www.Kaskus.co.id)

Mulyana, Y. Fitria. 2016. Pengaruh Kepercayaan Persepsi Resiko Dan Keamanan Terhadap Minat Beli Konsumen Pada Toko Online (Studi Pada Toko Online OLX.Co.Id). Journal of Consumer Research. No. 28 pp. 326-346.

Nazar M. Dan Syahran 2012. "Pengaruh Privasi, Keamanan, Kepercayaan, Dan Pengalaman Terhadap Niat Untuk Bertransaksi Secara Online.

Nurrahmanto P,A. 2015. Pengaruh Kemudahan Penggunaan, Kenikmatan Berbelanja, Pengalaman Berbelanja Dan Kepercayaan Konsumen Terhadap Minat Beli Konsumen Di Situs Jual Beli Online Bukalapak.com.

Nugroho S. Adi, 2016 E-Commerce Teori dan Implementasi Ekuilibria, Yogyakarta.

Oktaviyanti. 2011. Pengaruh Dimensi Kepercayaan (Trush) Terhadap Partisipasi Pelanggan E-Commerce.

Opida. 2014. Pengertian E-Marketplace:. https://tokokhalista.worpress.com/2019/05/

Park, Chung-Hoon., and Young-Gul Kim., 2006, "The Effect of Information Satisfaction and Relational Benefit on Consumers Online Site Commitmennts", Journal of Electronic Commerce in Organizations, 4 (1)

Pavlou, P. A. 2010, "Consumer acceptance of electronic commerce: Integrating trust and risk with the technology acceptance model." International Journal of Electronic Commerce, Vol. 7 (3).

R Dias Y. U, t. 2012. Pengaruh Privasi, Keamanan,Kepercayaan Dan Pengalaman Mahasiswa Terhadap Niat Bertransaksi Secara Online.

Rini W. 2014 Analisis Pengaruh Kepercayaan, Keamanan Dan Kepuasan Terhadap Minat Beli Konsumen Online Shop Olx (Studi Kasus Pada Mahasiswa Universitas Gunadarma). Rofiq Ainur. Pengaruh Dimensi Kepercayaan (Trust) Terhadap Partisipasi Pelanggan E-Commerce (Studi Pada Pelanggan E-Commerce di Indonesia).

Rizwan, M., Qoyyum, M., Qadeer, W., \& Javed, M. 2014. The Impact On Branded Product On Consumer Purchase Intentions. Journal of Public Administration and Governance, 4(3), 57-74

Simamora. 2011. Memenangkan Pasar dengan Pemasaran Efektif dan Profitabel. Jakarta: PT. Gramedia Pustaka Utama

Syaifudin M. 2014. Analisis Pengaruh Privasi Keamanan Dan Kepercayaan Terhadap Niat Untuk Bertransaksi Secara Online Di OLX.co.id. 
Shomad C. A. 2012. Pengaruh Kepercayaan, Persepsi Kegunaan, Persepsi Kemudahan, dan Persepsi Risiko Terhadap Perilaku Penggunaan E-Commerce.

Safina N. 2014. dengan judul Pengaruh Kepercayaan, Persepsi Resiko, Persepsi Manfaat, dan Persepsi Kontrol Perilaku Terhadap Niat Penggunaan Sistem E-commerce.

Sugiyono. 2008. Metode Penelitian Bisnis. Bandung: CV. Alfabeta.

Sugiyono. 2012. Metodologi Penelitian Bisnis. CV Alfabeta.Bandung.

Sumarwan, U. (2011). Perilaku Konsumen: Teori dan Penerapannya dalam Pemasaran. Edisi 2 Cetakan 1, Jakarta: PT Ghalia Indonesia

U Narimawati. 2015. Membuat Skripsi, Tesis dan Disertasi dengan Partial Least Square SEM (PLS-SEM). Yogyakarta: Penerbit ANDI.

Wu, S.I. \& Chen, Y.J. (2014). The Impact of Green Marketing and Perceived Innovation on Purchase Intention for Green Products. International Journal of Marketing Studies, 6(5), 1-20

Yacob, S, et,al. 2018. Pemanfaatan Social Commerce terhadap keunggulan bersaing dan implikasinya bagi kinerja bisnis UMKM di Provinsi Jambi.

Yacob, S. et,al. 2016. Do Really Competitive Strategy and Strategic Alliances Effect Retail Business Performance? Evidence From the Minimarket Retail in Jakarta and Bandung City,In Indonesia, International Journal of Economics, Commerce and Management, United Kingdom, Vol.IV Issue 2, pp 783-796

Yutadi P, K. 2014. Pengaruh Persepsi Privasi, Persepsi Keamanan, Persepsi Kepercayaan, Persepsi Risiko, Persepsi Kegunaan Dan Persepsi Kemudahan Penggunaan Terhadap Minat Penggunaan E-commerce.

Zaki Baridwan P. S. 2012. Penerimaan sistem E commerce : Pengaruh Kepercayaan, Persepsi Manfaat Dan Persepsi Risiko. 